\title{
Analisis Kesalahan Ortografi Bahasa Arab Mahasiswa Pendidikan Bahasa Arab Universitas Muhammadiyah Malang
}

\author{
Anisatu Thoyyibah \\ Universitas Muhammadiyah Malang \\ e-mail: anisatu_thoyyibah@umm.ac.id
}

\begin{abstract}
This article is a study of Arabic Language Education students at the University of Muhammadiyah Malang concerning spelling errors in writing Arabic characters. Orthography or Arabic alphabet spelling is a system that is generally used to realize the sound description from spoken language to written language in a language community, in this case Arabic. But in practice not everyone is able to describe the sound of language into writing correctly. Including students in the Arabic Language Study Program, University of Muhammadiyah Malang. This research is a descriptive type, in collecting data using observation techniques, documentation techniques, and interview techniques. The data analysis uses the orthographic equivalent method with basic techniques (orthographic sorting techniques) and advanced techniques (comparative correlation techniques). While the presentation of data uses informal variety. The results showed that the forms of orthographic errors or Arabic characters were first, one type of error consisting of adding vowels, reducing vowels or consonants, reducing consonant punctuation, and changing letters. Second, two or more types of errors. The factors underlying these mistakes are in terms of sociolinguistics and psycholinguistics. Keywords: Phonology, The orthography, language acquisition
\end{abstract}

\begin{abstract}
Abstrak
Artikel ini merupakan penelitian yang dilakukan terhadap mahasiswa Pendidikan Bahasa Arab Universitas Muhammadiyah Malang yang berkenaan kesalahan ejaan dalam penulisan aksara bahasa Arab. Ortografi atau ejaan aksara bahasa Arab merupakan sistem yang digunakan secara umum untuk mewujudkan gambaran bunyi dari bahasa lisan menjadi bahasa tulisan dalam masyarakat suatu bahasa, dalam hal ini bahasa Arab. Namun pada praktiknya tidak semua orang mampmenggambarkan bunyi bahasa ke dalam sebuah tulisan dengan benar. Termasuk juga para mahasiswa di program studi
\end{abstract}


Pendidikan Bahasa Arab, Universitas Muhammadiyah Malang. Penelitian ini berjenis deskriptif, dalam pengumpulan data menggunakan teknik observasi, teknik dokumentasi, dan teknik wawancara. Adapun analisis data menggunakan metode padan ortografik dengan teknik dasar (teknik daya pilah ortografis) dan teknik lanjutan (teknik hubung banding). Sedangkan penyajian data menggunakan ragam informal. Hasil penelitian menunjukkan bahwa bentuk kesalahan ortografi atau aksara bahasa Arab yaitu pertama, satu jenis kesalahan yang terdiri dari penambahan huruf vokal, pengurangan huruf vokal maupun konsonan, pengurangan tanda baca konsonan, dan perubahan huruf. Kedua, dua jenis kesalahan atau lebih. Adapun faktor yang melatarbelakangi kesalahan tersebut adalah dari segi sosiolinguistik dan psikolinguistik.

Kata kunci: Fonologi, Ortografi, Pemerolehan Bahasa

\section{Pendahuluan}

Bahasa merupakan salah satu sarana untuk berkomunikasi dengan sesama manusia. Dengan bahasa seseorang dapat mengekspresikan apa saja dalam fikirannya. Terdapat empat keterampilan dalam berbahasa yaitu, keterampilan mendengar, keterampilan berbicara, keterampilan membaca, dan keterampilan menulis. Istilah tersebut dalam bahasa Arab secara berurutan bisa disebut dengan (maharah al-Istima'), (maharah al-kalam), (maharah al-qira'ab), dan (maharah al-kitabah). Sedangkan dalam bahasa Inggris disebut dengan listening skill, speaking skill, reading skill, dan writing skill.

Keterampilan menulis (maharah al-kitabab) merupakan sebuah keterampilan yang menitikberatkan kepada keterampilan komunikatif dalam bahasa tulis. Menurut Tarigan sebagaimana dikutip oleh Vera Sardila menulis yaitu mencurahkan gagasan atau ide dengan menggunakan media tulis sebagai sarana penyampai. ${ }^{1}$ Pendapat lain dikemukakan M. Atar Semi dengan pengutip yang sama, bahwa menulis merupakan sebuah proses kreatif yang memindahkan sebuah gagasan ke dalam tulisan. ${ }^{2}$

al-Maharah al-Kitabah dalam bahasa Arab didefinisikan sebagai "Ibarah 'an naqli al-tafkir fi anmat $\}$ min al-rumuz, tu'abbir 'an al-maqasid wa al-badaf al-mukbtalifah kama tu'abbir 'an bajah al-katib". Bermakna "transfer pemikiran dalam pola-pola

${ }^{1}$ Vera Sardila, 'Strategi Pengembangan Linguistik Terapan Melalui Kemampuan Menulis Biografi Dan Autobiografi: Sebuah Upaya Membangun Keterampilan Menulis Kreatif Mahasiswa', An-Nida', 40.2 (2015).

${ }^{2}$ Ibid.

${ }^{3}$ Muhammad Fayiz Abu Diah, 'Atsar Istikhdam Haqaib Al-'Amal Fi Tanmiyah AlMaharah Al-Kitabiyah Lada Talamid Al-Shof Al-Tsalis Aal-Asasi Bi Ghaza' (Al-Jamiah alIslamiyah Ghaza, 2016). 
simbol yang mencerminkan maksud, tujuan, seperti mendeskripsikan kebutuhan penulis".

Hal ini dapat disimpulkan bahwa keterampilan menulis (maharah alkitabah) merupakan sebuah keterampilan yang menuangkan sebuah ide, gagasan, pendapat, perasaan yang ada dalam jiwa secara logis dan sistematis dari bahasa lisan ke bahasa tulisan.

Zulhannan berpendapat bahwa menulis dapat diklasifikasikan menjadi dua hal yaitu menulis bebas dan menulis terbimbing. ${ }^{4}$ Menulis bebas merupakan menulis yang dapat diaplikasikan berupa menulis insya' atau karangan dengan minim bimbingan. Sedangkan menulis terbimbing secara sederhana dapat berupa menyalin, memodifikasi kalimat, tabdil (substitusi), tahwil al-fi'il al-madi ila al-fi'il al-mudzari' (transformasi al-fi'il al-madi menjadi al-fi'il al-mudzari'), takmilah aljumlah (melengkapi kalimat), dan sebagainya. Baik kalimat atau jumlah yang komplek maupun sederhana.

Kalimat atau jumlah dalam sintaksis menempati objek terbesar, adapun objek terkecilnya adalah kata atau kalimah. Sedangkan kata atau kalimah dalam morfologi merupakan objek terbesarnya. Kata dalam Kamus Besar Bahasa Indonesia adalah satuan bahasa yang dapat berdiri sendiri dan dianggap sebagai satuan terkecil yang diucapkan maupun dituliskan berupa perwujudan dari sebuah pikiran dan perasaan yang dapat digunakan dalam berbahasa.

Pada praktik berbahasa, beberapa kesalahan dilakukan para mahasiswa pembelajar bahasa asing khusunya pembelajar bahasa Arab dalam mentransfer bahasa lisan ke dalam bahasa tulisan yang diwujudkan dalam aktivitas menulis rangkaian huruf menjadi sebuah kata yang tersusun dalam kalimat. Misalnya kata menjadi يشرب ,البستن menjadi رمى ريسرب dan sebagainya.

Penulis membatasi penelitian ini dalam skup kata atau kalimah dalam hal bentuk kesalahan ortografis bahasa Arab dan faktor yang melatarbelakangi terjadinya kesalahan tersebut pada para mahasiswa program studi Pendidikan Bahasa Arab semester II di Fakultas Agama Islam Universitas Muhammadiyah Malang, tahun ajaran 2017-2018 yang ditilik dari segi fonetik-fonologi dan sosiopsikolinguistik.

Penelitian ini dikaji menurut sudut pandang ortografi atau grafonomi yang merupakan cabang linguistik yang mengkaji tentang ejaan dalam bentuk tulisan/grafis. ${ }^{5}$ Pada cabang linguistik ini dipelajari bagaimana mewujudkan bentuk bunyi ke dalam bentuk huruf dan bagaimana menyusun huruf-huruf tersebut menjadi konstruksi yang lebih besar yaitu berupa tulisan. Metode dalam

\footnotetext{
${ }^{4}$ Zulhannan, Teknik Pembelajaran Babasa Arab Interaktif (Jakarta: Rajawali Pers, 2015).

5 Muhammad Nur, 'Harmoni Bahasa Dari Perspektif Penerjemahan Dalam Kamus Pemadanan Istilah Teknis : Suatu Kajian Pustaka’, Ranah, 6.2 (2017), 119-36.
} 
penelitian ini berjenis deskriptif kualitatif, yang merupakan jenis dari kualitatif yang menggambarkan atau menganalisis sebuah kondisi atau peristiwa, pemikiran, sekelompok manusia pada masa tertentu. Dapat disebutkan bahwa deskriptif kualitatif yakni mendeskripsikan, menafsirkan, mengungkapkan kejadian atau fakta dari sebuah keadaan atau situasi atau fenomena yang terjadi saat berlangsungnya penelitian dengan menyuguhkan apa yang sebenarnya. ${ }^{6}$ Sedangkan sumber data diperoleh dari tugas harian dan hasil evaluasi belajar mahasiswa baik Ulangan Tengah Semester (UTS) maupun Ulangan Akhir Semester (UAS).

\section{Hasil dan Pembahasan}

Penelitian ini menggunakan beberapa teori dalam mengananlisis tahapan demi tahapan penelitian. Adapun teori yang digunakan dalam penelitian ini berkaitan dengan hal berikut:

\section{Ortografi}

Ortografi merupakan cabang linguistik yang mempelajari cara-cara mewujudkan bahasa dalam bentuk tulisan. Dapat dikatakan bahwa ortografi yaitu subdisiplin linguistik yang mempelajari ejaan. Istilah lain dari ortografi adalah grafonomi. Pada penelitian ini menggunakan ejaan fonologis dan ejaan silabis. Ejaan fonologis terbagi menjadi dua ejaan yakni ejaan fonetis ${ }^{7}$ dan ejaan fonemis ${ }^{8}$. Sedangkan ejaan silabi merupakan sebuah sistem ejaan yang menggunakan dasar suku kata. Dapat disimpulkan bahwa ortografi merupakan bentuk perwujudan bahasa lisan ke dalam bahasa tulisan.

1. Kata

Kata merupakan bagian kalimat yang merupakan satuan terkecil yang bisa berdiri sendiri dan memiliki arti. Kata dalam bahasa arab disebut dengan alkalimah. Klasifikasi kata atau kalimah dalam bahasa Arab terbagi menjadi tiga yakni ism (nomina), fi'il (verba), dan harf (partikel).' Ism (nomina) yaitu kata yang mengarah pada makna yang terdapat di dalamnya tanpa menghiraukan hubungan dengan waktu. Adapun fi'il (verba) yaitu sebuah kata yang mengandung makna mengarah pada sebuah peristiwa yang berpatokan dengan

\footnotetext{
${ }^{6}$ Anisatu Thoyyibah, 'Khutbah Thariq Bin Ziyad (Kajian Stilistika Arab)', Alfaz (Arabic $\begin{array}{lllll}\text { Literatures for Academic } & \text { Zealots), } & 6.2 & \text { (2018), } & \text { 109-26 }\end{array}$ <http://dx.doi.org/http://dx.doi.org/10.32678/alfaz>.

${ }^{7}$ Ejaan yang berusaha melambangkan setiap bunyi yang berbeda, baik bunyi tersebut membedakan arti ataupun tidak.

${ }^{8}$ Ejaan yang berupa bunyi berstatus fonem yang diperhitungkan dalam penentuan huruf yang digunakan.

${ }_{9}$ Anisatu Thoyyibah, 'Idiom Bahasa Arab Dan Bahasa Indonesia Yang Berunsur BendaBenda Alam (Kajian Sosiosemantik)' (UIN Sunan Kalijaga Yogyakarta, 2015).
} 
waktu atau kala tertentu. Sedangkan harf (partikel) merupakan sebuah kata yang memiliki makna jika bergandengan dengan kata lainnya. Dalam hal ini, penelitian terhadap objek kata atau kalimah dapat diamati dari klasifikasi tersebut.

2. Fonetik dan Fonologi

Fonetik dan fonologi merupakan salah satu kajian mikrolinguistik yang mengkaji tentang suara atau aswat yang diproduksi oleh alat ucap manusia. Fonetik yaitu pembahasan tentang bunyi yang memiliki fungsi tanpa memperhatikan perbedaan makna, dan objek fonetik disebut dengan fon. Sedangkan fonologi adalah kajian bunyi yang membedakan makna, dan objek penelitian fonologi disebut fonem.

3. Pemerolehan Bahasa Asing

Pemerolehan bahasa yang dalam bahasa Inggris disebut language acquisition merupakan sub bagian dari psikolinguistik, ${ }^{10}$ yang membahas mengenai proses penguasaan bahasa yang dilakukan oleh seseorang secara natural pada waktu belajar. Hal ini berkaitan dengan pemerolehan bahasa asing yang didapat oleh seseorang. Menurut Clark sebagaimana dikutip oleh Soenjono bahwa pembahasan psikolinguistik berkaitan dengan komprehensi, produksi, dan pemerolehan bahasa. ${ }^{11}$

Menurut Yukio sebagaimana diungkapkan Ahmad Habibi Syahid bahwa terdapat dua istilah dalam pemerolehan bahasa, ${ }^{12}$ pertama pemerolehan bahasa kedua atau second language acquisition (SLA) dan selanjutnya pemerolehan bahasa asing atau foreign language acquisition (FLA). Di mana kedua istilah ini tidak begitu ada perbedaan yang signifikan, hanya pada letak proses pemerolehan bahasa saat pembelajar berusaha untuk mempelajari bahasa tersebut atau disesuaikan dengan kondisi yang dilakukan atau dibuat.

Jika dianalogikan pada model sekolah di Indonesia, terdapat sekolah asrama yang akrab dengan istilah Islamic Boarding School (Pondok Pesantren Modern) yang menerapkan bahasa Arab dan bahasa Inggris sebagai komunikasi sehari-hari, dalam hal ini bisa digunakan istilah FLA. Serta non asrama atau sekolah biasa yang hanya mempergunakan bahasa asing saat pelajaran berlangsung dan tidak dipergunakan dalam keseharian, yang disebut dengan SLA.

Pada penelitian ini, lebih mengarah kepada aliran behaviorisme yang digagas oleh Skinner bahwa bahasa diterapkan menggunakan model Stimulan-

\footnotetext{
${ }^{10}$ Membahas mengenai bahasa dan hubungannya dengan faktor kejiwaan pembicara dan lawan bicara.

11 Soenjono Dardjowidjojo, Psiko-Linguistik Pengantar Pemahaman Bahasa Manusia, Kedua (Jakarta: Yayasan Pustaka Obor Indonesia, 2016).

12 Ahmad Habibi Syahid, 'Bahasa Arab ..., 86-97.
} 
Respon (SR) yaitu keterampilan bahasa dibutuhkan sebuah penguatan, pengulangan, dan latihan yang memadai.

4. Multilingualisme, Pendidikan dan Pengajaran Bahasa

Kajian multilingualisme, pendidikan dan pengajaran bahasa merupakan sub kajan dari sosiolinguistik yaitu cabang linguistik yang mempelajari tentang bahasa yang berkaitan dengan para pengguna bahasa dalam sebuah masyarakat. Pengguna bahasa dalam lingkup ini mengacu pada masyarakat kampus yang lebih tepatnya pada mahasiswa program studi Pendidikan Bahasa Arab semester II di Fakultas Agama Islam Universitas Muhammadiyah Malang tahun ajaran 2017-2018.

Multilingualisme merupakan aktivitas menggunakan lebih dari dua bahasa oleh seorang penutur dalam berinteraksi dengan orang lain secara bergantian, ${ }^{13}$ dapat juga dikatakan kemampuan seseorang dalam menggunakan beberapa bahasa dengan sama baik atau hampir baiknya.

Sedangkan pendidikan dan pengajaran bahasa merupakan sebuah proses yang dapat mengubah sikap dan kemampuan seseorang (yaitu peserta didik) menjadi lebih baik setelah mengikuti proses dan aktivitas tersebut. ${ }^{14}$ Pada ranah ini pendidikan dan pengajaran lebih terpusat pada pendidikan dan pengajaran bahasa asing atau bahasa Arab, dengan melihat faktor-faktor pendukung maupun yang melatarbelakangi proses pendidikan dan pengajaran bahasa tersebut.

\section{Analisis Kesalahan Ortografi Bahasa Arab}

Menulis merupakan salah satu dari empat keterampilan berbahasa, selain membaca, mendengarkan, dan berbicara. Secara urut dalam bahasa Arab disebut dengan kitabah, qiraah, istima', dan kalam. Sebagaimana tertuang dalam situs website alukah.net bahwa kitabah atau menulis merupakan sebuah aktivitas yang kompleks yaitu kemampuan dalam mengekspresikan, menggambarkan, serta memvisualisasikan ide-ide atau pemikiran yang dituangkan dalam sebuah huruf, kata, dan kalimat yang tepat sehingga menjadi sebuah paragraf maupun wacana yang apik untuk dibaca. ${ }^{15}$

Sebagaiman disebutkan di muka, bahwa penelitian ini lebih mengarah pada sebuah kata atau kalimah yang telah ditulis oleh para narasumber dalam hal ini mahasiswa program studi Pendidikan Bahasa Arab yang duduk pada semester

${ }^{13}$ Endang Sulistijani, 'Alih Kode Dalam Novel 9 Summers 10 Autumns Karya Iwan Setyawan', Sasindo, 3.1 (2015), 1-20.

14 Abdul Chaer dan Agustina Leonie, Sosiolinguistik Perkenalan Awal, Kedua (Jakarta: PT Rineka Cipta, 2010).

15 Ibrahim Ali Ribaba'ah, 'Ta'rif Al-Kitabah Wa Mafhumiha', 2016 $<$ https://www.alukah.net/literature_language/0/101098.</ 
II di Fakultas Agama Islam Universitas Muhammadiyah Malang tahun ajaran 2017-2018, dalam mata kuliah kitabah I dan II, serta qiraah I dan II.

Kata dalam bahasa Arab disebut kalimah merupakan satuan terkecil dari kalimat atau jumlah yang terdiri dari gabungan huruf. Satuan terkecil dari kata adalah morfem (suku kata). Kata sebagaimana diungkapkan Harimurti Kridalaksana yang dikutip oleh Sahkholid Nasution merupakan satuan bahasa yang bisa berdiri sendiri, terdiri dari morfem tunggal atau morfem gabungan. ${ }^{16}$

\section{Bentuk Kesalahan Ortografi Bahasa Arab}

Beberapa temuan terkait kesalahan penulisan kata atau ortografi yang pernah ditulis oleh mahasiswa program studi Pendidikan Bahasa Arab yang duduk pada semester II di Fakultas Agama Islam Universitas Muhammadiyah Malang tahun ajaran 2017-2018, sebagai berikut :

\section{Satu Jenis Kesalahan}

Kesalahan yang terjadi bertumpu pada satu jenis kesalahan, seperti penambahan huruf vokal, pengurangan huruf vokal maupun konsonan, pengurangan tanda baca konsonan, dan perubahan huruf. Adapun uraian kesalahan sebagaimana termaktub di bawah ini :

\section{a. Penambahan Huruf Vokal}

Satu jenis kesalahan yang pertama yaitu penambahan huruf vokal, diantaranya;

Tabel 1. Contoh Kesalahan Penambahan Huruf Vokal

\begin{tabular}{|c|c|}
\hline الأصحاء & الأخطاء \\
\hline مدّة & مدّاة \\
\hline المدرّس & المدارّس \\
\hline العربيّة & العرابيّة \\
\hline جميلة & جاميلة \\
\hline مهمّم & مهيمّ \\
\hline وسخ & واسخ,وسيخ \\
\hline
\end{tabular}

Kata المدرّس ب المدرّس

Kata al-mudarris dalam kalimat yajlisu al-mudarrisu 'ala al-kursiyyi, termasuk dalam kategori satu jenis kesalahan dengan penambahan huruf alif setelah huruf da. Huruf $d a$ menurut cara artikulasi termasuk dalam kategori hambat atau 107.

\footnotetext{
${ }^{16}$ Sahkholid Nasution, Pengantar Linguistik Bahasa Arab (Sidoarjo: CV. Lisan Arabi, 2017),
} 
letupan (al-infijariyah) yaitu huruf konsonan yang terjadi adanya proses menghambat penuh arus udara, dan dilepaskan secara tiba-tiba. ${ }^{17}$

Menurut pengamatan penelti, adanya huruf da yang dilepaskan secara tiba-tiba menjadikan hal tersebut memiliki kelebihan huruf vokal alif sebab huruf $d a$ berharakat fathah. Seyogyanya para pembelajar untuk tidak melepaskan huruf secara tergesa yang menjadikan huruf tersebut memanjang satu harakat. Penulisan yang benar yaitu al-mudarris yang berarti "pendidik/ guru/ dosen", kata ini termasuk dalam kategori ism al-mufrad.

Kata مهمّ Tهيم

Kata muhimmun dalam kalimat al-to'amu mubimmun lisibhah al-badani, termasuk dalam kategori satu jenis kesalahan dengan penambahan huruf ya setelah ha. Jika dilihat dari daerah artikulasi huruf ha termasuk dalam bunyi faringal atau golotals di mana bunyi dihasilkan dari merapatkan dua pita suara sehingga terjadi hambatan dari daerah paru-paru yang melewati di antara dinding belakang rongga kerongkongan dengan akar lidah. ${ }^{18}$

Huruf ha yang berharakat kasrah dengan penambahan huruf ya menjadikan vokal panjang atau al-harakah al-tawilah, yang membuat salah dalam pengucapan dan penulisan. Adapun penulisan yang benar yaitu mubimmun yang bermakna "penting", kata ini termasuk dalam kategori ism.

Kata

Kata wasikhun dan wasikhun dalam kalimat aknusu al-bilata al-wasikha dan aknusu al-bilata al-wasikha, juga termasuk dalam kategori satu jenis kesalahan. Penambahan huruf alif setelah wawn yang berharakat fathah menjadi al-h\}arakah al-tawilah atau vokal panjang.

Huruf wawn termasuk dalam bunyi bilabial (syafawiyab/ huruf bibir) di mana adanya bunyi tersebut dihasilkan dari pertemuan antara bibir bawah dengan bibir atas dengan keadaan bibir terkatup rapat yang menyebabkan udara dari dalam paru-paru tertahan dalam waktu singkat sebelum katupan tersebut dilepaskan. Saat melepaskan huruf wawn beberapa pembelajar bahasa Arab melepaskan huruf tersebut di luar ketentuan kata asli, dengan ketukan dua harakat atau panjang yang menjadikan salah dalam penulisan.

Sedangkan huruf sin masuk dalam bunyi avico-alveolars yang mana bunyi dihasilkan dari sentuhan ujung lidah ke gusi, mengakibatkan penyempitan saluran udara yang selanjutnya keluar secara perlahan tanpa letupan. Hal ini juga tidak berbeda dengan huruf sebelumnya bahwa huruf sin berharakat kasrah

${ }^{17} \mathrm{Ibid}, 83$.

${ }^{18}$ Ibid, 82-83. 
sehingga para pembelajar bahasa Arab memanjangkan dua harakat atau vokal panjang yang hal itu merupakan sebuah kesalahan. Adapun kata yang benar yaitu wasikhun yang bemakna "kotor", dan termasuk dalam kategori kata sifat atau ism al-sifah.

\section{b. Pengurangan Huruf Vokal maupun Konsonan}

Satu jenis kesalahan yang kedua yaitu pengurangan huruf vokal maupun konsonan, diantaranya;

Tabel 2. Contoh Kesalahan Pengurangan Huruf Vokal

\begin{tabular}{|c|c|}
\hline الأصححاء & الأخطاء \\
\hline اللحم & الحم \\
\hline الصغيرة & الصغرة \\
\hline سباحة & سبحة \\
\hline البستان & البستن \\
\hline واحد & وحد \\
\hline 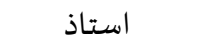 & استذ است \\
\hline كسلان & كسلن \\
\hline واسع, واسعة & وسع, وسعة \\
\hline كرّاسة & كرّسة \\
\hline تاريخ & تارخ, التريخ \\
\hline الدكان & الدكن \\
\hline سلمى & سلم سم \\
\hline كبيرة & كبرة \\
\hline طالب & طلب \\
\hline اقلام & أقلم \\
\hline فياه & فه \\
\hline ألأدوات - أدوات & ألّدّوات \\
\hline حقيبة & حقبة \\
\hline ثمانياة & ثمنية \\
\hline الأستاذ & الستاذ \\
\hline ملابس & ملبس \\
\hline سيّارة & سيّرة \\
\hline
\end{tabular}


324 | Arabiyatuna : Jurnal Bahasa Arab, Vol. 3, No. 2, 2019

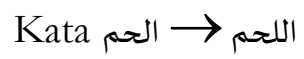

Kata alahmu dalam kalimat masaka al-ba'i'u alahma mengalami kesalahan pengurangan huruf konsonan. Pengurangan pada huruf " $\mathrm{J}$ "//, secara artikulasi huruf tersebut termasuk dalam bagian lateral atau sampingan (al-aswat aljanibiyyah) yaitu ujung lidah bersentuhan dengan gusi dan udara keluar melalui sebelah lidah. ${ }^{19}$

Secara struktur terdiri dari لحم+ال, karena huruf pertama dari kata tersebut juga berbunyi "J", pembelajar bahasa Arab seolah-olah mencampuradukkan huruf " "ل" asli dan "J" partikel, yang berakibat pada berkurangnya huruf. Sedangkan penulisan yang benar adalah al-lahmu atau labmun yang memiliki makna "daging", dan kata ini masuk dalam kelas ism alma'rifah.

طالب Mata - ملب

Kata talib dalam kalimat ta'allama talib al-darsa mengalami kesalahan pengurangan huruf vokal, yaitu pengurangan terhadap huruf "I" atau alif yang sebelumnya berharakat fathah. Vokal "l" atau alif dan harakat fathah merupakan vokal depan, rendah, dan tidak bundar. ${ }^{20}$ Vokal ini dibuat dengan bagian terendah dari lidah terletak pada posisi sedang dalam rongga mulut.

Kata thalib berubah menjadi thalib, jika kata tersebut tidak berharakat, maka sekilas pembaca akan membaca kata $t\}$ alib menjadi $t\} a l a b a$ kata kerja lampau (fi'il madhi) yang memiliki arti "meminta". Namun mahasiswa menuliskannya dengan harakat pendek, dalam hal ini mencampuradukkan dua kata yang memiliki makna berlainan.

Secara bunyi bahasa pada vokal, salah satu faktor yang melatarbelakangi hal tersebut terletak pada tinggi rendahnya posisi lidah. Sehingga mahasiswa keliru dalam pengucapan yang kemudian ditransfer ke dalam bentuk tulisan. Adapun penulisan kata yang benar adalah thalib yang memiliki arti "mahasiswa atau murid", yang mana kata ini termasuk dalam kategori ism al-fa'il.

Kata كبيرة

Kata kabiratun dalam kalimat al-sayya>ratu kabiratun, mengalami kesalahan pengurangan huruf vokal "ي "ي "ي " atau /y/. Vokal ya dan harakat kasrah masuk dalam ranah vokal depan, tinggi, dan tidak bulat. Pada

${ }^{19}$ Moch. Syarif Hidayatullah, Cakrawala Linguistik. Arab (Jakarta: PT Grasindo, 2017), 47.

${ }^{20} \mathrm{Ibid}, 42$. 
saat mengucapkan bunyi vokal ini posisi lidah terletak pada posisi depan yang dibuat di bagian tertinggi lidah pada rongga mulut.

Pengurangan vokal "ي " pada kata kabiratun yang dilakukan oleh mahasiswa seolah-olah menunjukkan sebuah pelesapan yaitu melesapkan huruf ya pada harakat kasrah di huruf ba. Sehingga menjadikan kata tersebut berharakat pendek, yang seharusnya berharakat panjang.

Pada dasarnya vokal "ي atau /y/ termasuk dalam vokal tinggi, namun adanya faktor tinggi-rendah posisi lidah dan depan-belakang lidah menyebabkan kesalahan pelesapan tersebut. Sedangkan penulisan yang benar yaitu kabi>ratun yang bermakna "besar". Kata ini termasuk dalam kategori ism al-s\}ifah.

\section{c. Pengurangan Tanda Baca Konsonan}

Satu jenis kesalahan yang ketiga yaitu pengurangan tanda baca konsonan, diantaranya:

Tabel 3. Contoh Kesalahan Pengurangan Tanda Baca Konsonan

\begin{tabular}{|c|c|}
\hline أحتي & أخطاء \\
\hline أخسر & أختح \\
\hline يسرب & يسرح \\
\hline
\end{tabular}

Kata Kشرب ج

Kata yasrabu dalam kalimat yasrabu mahmud al-dawaa, termasuk dalam satu jenis kesalahan, karena hilangnya tanda baca titik tiga di atas huruf. Fonem " " " " " /sy/ pada kata yasrabu dan yasyrabu masuk dalam kategori pasangan minimal yang memiliki kedekatan bunyi suara. Keduanya juga memiliki arti masing-masing secara berurutan bocor dan minum.

Secara artikulasi, kedua huruf tersebut masuk dalam kategori konsonan geseran atau frikatif al-ihtikakiyah), ${ }^{21}$ yaitu huruf yang dihasilkan melalui penyempitan arus udara dari paru-paru yang menjadikan terhalangnya jalan udara dan keluar dengan bergesar.

Kedua huruf ini juga termasuk dalam konsonan tidak bersuara atau almahmusah di mana pita suara tidak ikut bergetar ketika bunyi tersebut diucapkan atau artikulasikan. Adanya persamaan ini kiranya yang menjadikan 47.

${ }^{21}$ Moch. Syarif Hidayatullah, Cakrawala ..., 83; Sahkholid Nasution, Pengantar Linguistik ..., 
pembelajar bahasa Arab keliru dalam pengucapan sebuah kata. Sedangkan penulisan yang benar yaitu yasyrabu dengan makna "minum atau meminum". Kata tersebut masuk dalam kategori fi'il mud\} $a>r i$ '.

Kata أختي $\rightarrow$

Kata uhtiy dalam kalimat t\}abakhat uhtiy al-kabiratu al-dajajata, mengalami kesalahan penulisan dalam pengurangan satu titik dalam huruf

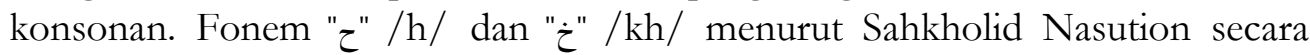
artikulasi kedua fonem tersebut memiliki kesamaan yaitu sama-sama termasuk konsonan yang dihasilkan melalui penghambatan jalan arus udara yang dihembuskan ke paru-paru, sehingga jalan keluarnya menjadi bergeser. ${ }^{22}$

Namun dari ranah daerah artikulasi kedua huruf tersebut memiliki perbedaan. Fonem " $\tau$ " /h/ termasuk dalam bunyi root-pharyngeals atau jaza>r hjalqiy di mana bunyi yang dihasilkan dengan mendekatkan akar lidah ke dinding rongga kerongkongan akan tetapi tidak sampai menyentuhnya.

Sedangkan fonem " $"$ " /kh/ tergolong dalam bunyi dorso-velar yang mana bunyi yang dihasilkan dengan menempelkan belakang lidah pada langitlangit lunak. Persamaan dan perbedaan inilah yang menyebabkan terjadinya kesalahan pengurangan satu titik pada huruf tersebut. Adapun penulisan yang benar yaitu ukbtiy yang memiliki makna "saudara perempuan", kata ini termasuk dalam kategori ism muannats.

\section{d. Perubahan Huruf}

Satu jenis kesalahan yang keempat yaitu perubahan huruf, diantaranya;

Tabel 4. Contoh Kesalahan Perubahan Huruf

\begin{tabular}{|c|c|}
\hline الأصحاء & الأخطاء \\
\hline أخت & أخة \\
\hline محفظة & محفضية \\
\hline قسم & كسم \\
\hline حقيبة & حقيبط \\
\hline مقلمة مق مق & مكلمة، معلمة \\
\hline كرّاسة & قرّاسة \\
\hline تتأخر & تتعخر \\
\hline الثامن & السامن \\
\hline عشرة & اشرة \\
\hline
\end{tabular}

22 Sahkholid Nasution, Pengantar Linguistik ..., 83. 


\begin{tabular}{|c|c|}
\hline استذكر & استثكر \\
\hline المثال & المسال \\
\hline ألة & عالة \\
\hline يذكر ل & يزكر \\
\hline مهمَّ & محمّ م محز \\
\hline بركة & برقة \\
\hline اقلام & عقلام \\
\hline الثّانية & السيّانية \\
\hline ممسحة & ممسههة \\
\hline المائدة & الماعدة \\
\hline العائلة & العاعلة \\
\hline الغرفة & الغرف ت \\
\hline نشيطة & نصيطة،, ناشطة \\
\hline
\end{tabular}

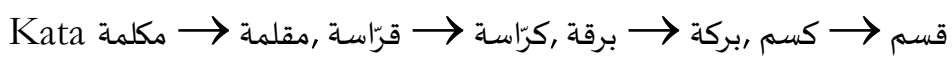

Kata miklamatun dalam kalimat al-miklamatu 'ala> al-maktabi, kata qurra $>$ satun dalam frasa qurra $>$ satun jadi $>$ datun, kata birqatun dalam frasa birqatun wa $>$ si'atun, dan kata kismun dalam kalimat kismu ta'li $>m$ al-lughah al-'arabiyyah mengalami kesalahan pergantian huruf. Fonem "ك" "ق" / " " / / / dan / masuk dalam kelompok pasangan minimal yang memiliki kedekatan bunyi suara.

Secara artikulasi kedua huruf tersebut masuk dalam kelas konsonan hambat atau letupan (al-infijariyah/stops), ${ }^{23}$ dihasilkan dengan cara menghambat udara secara total sehingga tidak ada ada udara yang berlalu, kemudian dilepaskan secara tiba-tiba.

Kedua huruf ini juga termasuk dalam kluster konsonan tidak bersuara atau al-mahmusah yaitu pita suara tidak ikut bergetar ketika bunyi tersebut diucapkan atau artikulasikan. Adanya persamaan-persamaan ini kiranya yang menjadikan pembelajar bahasa Arab salah dalam pengucapan sebuah kata.

Adapun penulisan yang benar dari kata-kata tersebut adalah miqlamatun bermakna tempat pensil, kata kurrasatun memiliki makna "buku tulis", kata birkatun berarti "kolam", dan kata qismun artinya "bagian" atau dalam konteks frasa tersebut memiliki arti "program studi".

${ }^{23}$ Moch. Syarif Hidayatullah, Cakrawala ..., 83; Sahkholid Nasution, Pengantar Linguistik ..., 47. 
Kata محفظة $\rightarrow$ محفضية

Kata mab\}fad\}atun dalam kalimat ghasalat mab\}mu>dab mab\}fad\}\}atan, mengalami kesalahan dalam segi pergantian huruf. Fonem "ض /d/ dan " "ط / / masuk dalam kelompok pasangan minimal yang memiliki kedekatan bunyi suara.

Menurut tempat artikulasinya, fonem "ض /d/ masuk bagian dalam bunyi apico-denal-alveolar atau lamionalveolar (al-aswat al-asnaniyyah al-litsawiyyab), yaitu depan lidah menjadi artikulator aktif dan gusi menjadi artikulator pasif. ${ }^{24}$ Sedangkan fonem "ל /z/ termasuk dalam bunyi interdental (al-aswat bain alAsnan), yaitu pinggir lidah menjadi artikulator aktif dan gigi atas menjadi artikulator pasif.

Adapun menurut keadaan pita suara, kedua huruf ini masuk dalam kluster konsonan bersuara atau al-Samitah al-Majhurah yaitu di mana pita suara bergetar pada saat bunyi dilafalkan. Adanya persamaan dan perbedaan kedua huruf tersebut, berdampak pada kesalahan dalam pengucapan dan penulisannya. Sedangkan penulisan kata yang benar adalah mabfazatun yang memiliki arti "tas", kata tersebut masuk dalam kategori ism.

Kata نشيطة $\rightarrow$ نصيطة

Kata nasitatun dalam kalimat khodijah hiya talibatun nasyitatun, mengalami kesalahan dalam pergantian huruf. Fonem " "ش" / / / / d / dan/ juga termasuk dalam kelompok pasangan minimal yang memiliki kedekatan dalam bunyi suara.

Dari segi tempat artikulasi, fonem "ص / / / masuk dalam apicoalveoral atau al-Aswat al-Lisawiyyah yaitu pinggir lidah menjadi artikulator aktif dan gusi menjadi artikulator pasif. ${ }^{25}$ Sedangkan fonem termasuk dari bunyi palatal atau alAswat al-Hanaqiyyah yaitu tengah lidah menjadi artikulator aktif dan bagian langit-langit mulut menjadi artikulator pasif.

Adapun dari faktor keadaan pita suara, kedua huruf tersebut termasuk dalam bunyi konsonan tidak bersuara atau al-mahmusah, yaitu pita suara tidak bergetar ketika bunyi tersebut diartikulasikan. Adanya faktor persamaan dari perbedaan dari kedua huruf tersebut menjadikan beberapa mahasiswa keliru dalam pengucapan dan penulisannya. Sedangkan penulisan kata yang benar adalah nasyitatun yang memiliki arti "rajin", kata tersebut masuk dalam kategori ism al-Sifah.

\section{Dua Jenis Kesalahan atau Lebih}

berikut:

Dua jenis kesalahan atau lebih yang ditemukan, diantaranya sebagai

\footnotetext{
${ }^{24}$ Moch. Syarif Hidayatullah, Cakrawala ..., 44.

${ }^{25}$ Idem, 45.
} 


\section{Tabel 5. Contoh Dua Bentuk Kesalahan atau Lebih}

\begin{tabular}{|c|c|}
\hline الأصحاء & الأخطاء \\
\hline المدرّس & المدالرّس \\
\hline يشتري & يستر \\
\hline 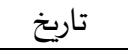 & 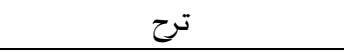 \\
\hline ديسمبير & ديسانبير, دى سمبر, دسامبير \\
\hline حقيبة & حاقبة \\
\hline المهمّة & المحيمّة \\
\hline أستاذك & الأستذك \\
\hline العاليي & العلامى \\
\hline 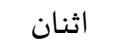 & عسنن \\
\hline أستاذ أستاذ & عستذ \\
\hline نشيطة & ناشطة \\
\hline طاولة & طويلة \\
\hline وسخ & وسقة \\
\hline الشّربة & السوربة \\
\hline
\end{tabular}

\section{Kata المهمّة ج المحيمّة}

Kata al-mubimmah mengalami dua jenis kesalahan dalam penulisan atau ortografi bahasa Arab. Pertama berubahnya huruf "ه"。/h/ dengan "ح" /h\}/, menurut kajian huruf yang berdampingan, kedua huruf ini juga termasuk di dalam klasifikasi pasangan minimal. Secara artikulasi, kedua huruf ini masuk dalam bagian konsonan frikatif atau geseran (al-ibtikakiyah) yaitu bunyi bahasa dihasilkan dari arus udara yang melalui saluran sempit lalu terdengar suara desis. $^{26}$

Kedua huruf ini termasuk dalam konsonan tidak bersuara (al-mahmu>sah) sebagaimana dijelaskan di muka. Dengan adanya artikulasi dan jenis konsonan yang sama menjadikan para pembelajar juga keliru dalam menuliskan hurufhuruf tersebut dalam rangkaian sebuah kata hingga menjadi kalimat.

Kesalahan kedua, terletak pada bertambahnya huruf vokal atau harakat panjang (al-harakah al-tawilah). Huruf / h/ yang berharakat kasrah atau harakat pendek (al-harakah al-qasirah) dalam pengucapan berubah menjadi panjang dalam tulisan. Hal ini disebabkan pembelajar bahasa Arab menambahkan dua ketukan atau meneruskan dua harakat dengan penambahan huruf /ya/, sehingga tulisan 
yang ditimbulkan juga panjang. Adapun penulisan yang benar yaitu al-mubimmah yang memiliki arti "penting", kata ini termasuk dalam kategori ism.

Kata يشتري ج يستر

Kata yastari dalam kalimat yastari mahmud al-Jawwlata mengalami dua jenis kesalahan, pertama berubahnya huruf "ش". /sy/ dengan "س" / /. Sebagaimana dijelaskan di muka bahwa dari segi artikulasi, kedua huruf ini masuk dalam kategori konsonan geseran atau frikatif (al-ibtikakiyah), yaitu huruf yang dihasilkan melalui jalur penyempitan arus udara dari paru-paru sehingga jalan udara menjadi terhalang dan keluar dengan bergesar. ${ }^{27}$

Kedua huruf tersebut juga termasuk dalam konsonan tidak bersuara atau al-mahmusah di mana pita suara tidak ikut bergetar ketika bunyi tersebut diucapkan atau artikulasikan. Adanya persamaan ini kiranya yang menjadikan pembelajar bahasa Arab keliru dalam pengucapan sebuah kata. Kesalahan kedua, berkurangnya huruf vokal panjang yaitu vokal "ي atau ya setelah harakat kasrah. Fonem kasrah atau /i/ termasuk vokal tinggi depan dengan kedua bibir terentang ke arah samping.

Sedangkan menurut cara artikulasi, huruf "ي" termasuk dalam bunyi semivokal atau hampiran yaitu artikulator aktif dan pasif membentuk ruang yang mendekati posisi terbuka seperti pada pembentukan vokal, tetapi tidak cukup untuk menghasilkan konsonan. Adanya bunyi semivokal menjadikan para mahasiswa samar-samar dalam pengucapan huruf dalam sebuah kata, yang berakibat pada kesalahan dalam ha penulisan. Adapun penulisan yang benar adalah yasytariy yang memiliki makna "membeli", kata ini termasuk dalam kategori fi'il mudari'.

Kata أستاذ ج

Kata 'ustar\} un dalam kalimat qama 'ustazu amama al-Fasli, mengalami dua jenis kesalahan. Kesalahan pertama yaitu berubahnya huruf "i". /alif/ menjadi "ع" /'ain/, vokal ini termasuk dalam kelompok pasangan minimal yang memiliki kedekatan dalam bunyi suara. Fonem /a/ masuk dalam vokal tengah pada posisi bagian tengah lidah agak merata dan mulut terbuka lebar.

Sedangkan fonem " $"$ " /'ain/ termasuk dalam bunyi root-pharyngeals atau jazar halqiy di mana bunyi yang dihasilkan dengan mendekatkan akar lidah ke dalam dinding rongga kerongkongan akan tetapi tidak sampai menyentuhnya. Adanya kedekatan dalam bunyi suara mengakibatkan salah dalam pelafalannya dan juga penulisannya.

${ }^{27}$ Moch. Syarif Hidayatullah, Cakrawala ..., 83; Sahkholid Nasution, Pengantar Linguistik ..., 47. 
Adapun kesalahan kedua yaitu pengurangan huruf vokal "I" atau alif yang sebelumnya berharakat fathah. Vokal "I" atau alif dan harakat fath\}ah merupakan vokal depan, rendah, dan tidak bundar. ${ }^{28}$ Vokal ini dibuat dengan bagian terendah dari lidah terletak pada posisi sedang dalam rongga mulut. Adanya vokal rendah memungkinkan mahasiswa tidak membacanya dalam sebuah kalimat. Penulisan yang benar yaitu ustazun yang memiliki makna "guru/ dosen", kata ini termasuk dalam kategori ism.

\section{Faktor yang Melatarbelakangi Kesalahan Ortografi Bahasa Arab}

Sebagaimana disebutkan di muka, bahwa ortografi atau aksara dipergunakan untuk merekam dan menuliskan bunyi bahasa Arab yang diucapkan oleh para penuturnya, dalam hal ini penutur bahasa Arab. dan menulis adalah turunan penggunaan bahasa atau turunan dari bahasa lisan yang menyesuaikan dengan bentuk bunyi dan perubahannya.

Faktor yang mempengaruhi kesalahan ortografi atau aksara bahasa Arab ditengarai oleh faktor psikolinguistik dan sosiolinguistik. Dari ranah psikolinguistik, pemerolehan bahasa Arab para mahasiswa program studi Pendidikan Bahasa Arab beraneka ragam. Dari 38 mahasiswa yang menjadi sampel, 11 mahasiswa berasal dari Pondok Pesantren, 16 mahasiswa dari MAN/MA, 8 mahasiswa dari SMAN/ SMA, 2 mahasiswa dari SMK, dan 1 orang dari sekolah luar negeri.

Secara garis besar hampir $71 \%$ mahasiswa pernah mempelajari bahasa Arab, namun para pembelajar bahasa Arab terkadang masih mencampur adukkan bahasa pertama maupun bahasa kedua. Contoh kata السامن ditulis الثامن oleh salah satu mahasiswa atau pembelajar bahasa Arab. Setelah dilakukan observasi, ternyata mahasiswa juga keliru dalam hal pengucapan atau pelafalan kata tersebut.

Peneliti juga melakukan wawancara dan melihat data yang tertulis, bahwa mahasiswa yang dimaksut berasal dari daerah Tangerang Selatan yang mana menggunakan bahasa Betawi, Sunda, sebagian Jawa dalam berkomunikasi. Hal ini mempengaruhi mahasiswa dalam pemerolehan dan pembelajaran bahasa asing atau bahasa Arab.

Dari segi sosiolinguistik, mahasiswa atau para pembelajar bahasa Arab dalam praktiknya tidak hanya mempelajari satu bahasa asing saja selain bahasa pertama di mana mereka dilahirkan, dan bahasa kedua atau bahasa Indonesia, tetapi para mahasiswa juga belajar bahasa Inggris baik ketika menjadi siswa maupun mahasiswa seperti saat ini. Istilah ini akrab dengan sebutan multilingualisme yaitu penutur yang mempelajari lebih dari dua bahasa.

${ }^{28}$ Moch. Syarif Hidayatullah, Cakerawala ..., 42. 
Hal ini juga menimbulkan sebuah masalah dalam pembelajaran bahasa asing seperti diungkapkan Abdul Chaer yaitu sejauh mana penguasaan para pembelajar bahasa, yang dipelajari di antara bahasa-bahasa tersebut terutama bahasa asing? Apakah semuanya baik atau salah satu saja yang menonjol? dan Sejauh mana pengaruh antar bahasa satu ke bahasa lain?. ${ }^{29}$

Dari pertanyaan-pertanyaan tersebut, tidak banyak yang bisa menguasai keseluruhan bahasa yang telah dipelajari, dari pengamatan yang ada para pembelajar bahasa kebanyakan hanya condong di salah satu bahasa saja dalam hal ini bahasa Arab meskipun para pembelajar belajar di program studi Pendidikan Bahasa Arab, namun terdapat faktor interferensi ${ }^{30}$ yang dialami oleh para pembelajar.

Sebagai contoh kata المائدة berubah menjadi الماعدة dalam pengucapan dan penulisan. Menurut pengamatan peneliti, para pembelajar multilingual ingin tampil fasih dalam pengucapan dan di transfer dalam bentuk tulisan, namun sebaliknya kefasihan dalam pengucapan membuat kata yang diucap menjadi tidak tepat dan tidak bermakna.

Faktor-faktor inilah yang kiranya menyebabkan terjadinya kesalahan ortografi bahasa Arab di program studi Pendidikan Bahasa Arab, Fakultas Agama Islam, Universitas Muhammadiyah Malang.

\section{Penutup}

Dari penelitian yang dilakukan oleh peneliti ditemukan beberapa model kesalahan ortografi bahasa Arab yang dilakukan oleh para mahasiswa program studi Pendidikan Bahasa Arab, Fakultas Agama Islam, Universitas Muhammadiyah Malang.

Adapun model kesalahannya adalah pertama, satu jenis kesalahan yang terdiri dari penambahan huruf vokal, pengurangan huruf vokal maupun konsonan, pengurangan tanda baca konsonan, dan perubahan huruf. Kedua, dua jenis kesalahan atau lebih. Dari model kesalahan-kesalahan tersebut, kesalahan yang mendominasi mahasiswa program studi Pendidikan Bahasa Arab semester II di Fakultas Agama Islam Universitas Muhammadiyah Malang tahun ajaran 2017-2018 yaitu pengurangan huruf vokal maupun konsonan dan perubahan huruf.

Sedangkan faktor yang melatarbelakangi kesalahan ortografi diantaranya yaitu dari segi psikolinguistik dan sosiolinguistik. Dari ranah psikolinguistik, pemerolehan bahasa Arab para mahasiswa berasal dari beraneka ragam seperti

\footnotetext{
${ }^{29}$ Abdul Chaer dan Agustina Leonie, Sosiolinguistik ..., 85.

30 Adanya serpihan yang tampak dalam suatu bahasa baik dari fonologi, morfologi, maupun sistem lainnya.
} 
pondok pesantren, Madrasah Aliyah maupun Tsanawiyah, Sekolah Menengah Umum atau Kejuruan, dan sekolah dari luar negeri.

Ranah sosiolinguistik, para mahasiswa termasuk dalam kategori masyarakat multilingualisme yang mana tidak hanya satu bahasa asing yang dipelajari selain bahasa Indonesia maupun bahasa daerah masing-masing. Selain itu asal daerah mahasiswa juga turut mempengaruhi proses pembelajaran bahasa Arab.

\section{Bibliografi}

Aribowo, Eric Kunto, 'Fonologi Dan Ortografi Bahasa Arab', Seminar Nasional Bulan Bahasa Dan Sastra, 2013, 202-11

Chaer dan Agustina Leonie, Abdul, Sosiolinguistik Perkenalan Awal, Kedua (Jakarta: PT Rineka Cipta, 2010)

Dardjowidjojo, Soenjono, Psiko-Linguistik Pengantar Pemahaman Bahasa Manusia, Kedua (Jakarta: Yayasan Pustaka Obor Indonesia, 2016)

Diah, Muhammad Fayiz Abu, 'Atsar Istikhdam Haqaib Al-'Amal Fi Tanmiyah Al-Maharah Al-Kitabiyah Lada Talamid Al-Shof Al-Tsalis Aal-Asasi Bi Ghaza' (Al-Jamiah al-Islamiyah Ghaza, 2016)

Hidayatullah, Moch. Syarif, Cakrawala Linguistik Arab (Jakarta: PT Grasindo, 2017)

Jayanto, Eko, Dewi Kartika Ardiyani, and Deddy Kurniawan, 'Kesalahan Ortografi Pada Keterampilan Menulis Bahasa Jerman Siswa Kelas X-9 SMAN 1 Kepanjen', 2012

Mahsun, Metode Penelitian Bahasa - Tahapan Strategi, Metode, Dan Tekniknya, Revisi (Jakarta: Rajawali Pers, 2012)

Musthafa, Izzudin, and Acep Hermawan, Metodologi Penelitian Bahasa Arab: Konsep Dasar, Strategi, Metode, Teknik, Pertama (Bandung: PT Remaja Rosdakarya, 2018)

Nasution, Sahkholid, Pengantar Linguistik Bahasa Arab (Sidoarjo: CV. Lisan Arabi, 2017)

Ni'mah, Umi Nurun, 'Ortografi Arab Dan Problematikanya', Adabiyyat, XI (2012), 143-65

Nur, Muhammad, 'Harmoni Bahasa Dari Perspektif Penerjemahan Dalam Kamus Pemadanan Istilah Teknis: Suatu Kajian Pustaka', Ranah, 6 (2017), 119-36

Ribaba'ah, Ibrahim Ali, 'Ta'rif Al-Kitabah Wa Mafhumiha', 2016 <https://www.alukah.net/literature_language/0/101098/> 
334 | Arabiyatuna : Jurnal Bahasa Arab, Vol. 3, No. 2, 2019

Sardila, Vera, 'Strategi Pengembangan Linguistik Terapan Melalui Kemampuan Menulis Biografi Dan Autobiografi: Sebuah Upaya Membangun Keterampilan Menulis Kreatif Mahasiswa', An-Nida', 40 (2015)

Sulistijani, Endang, 'Alih Kode Dalam Novel 9 Summers 10 Autumns Karya Iwan Setyawan', Sasindo, 3 (2015), 1-20

Syahid, Ahmad Habibi, 'Bahasa Arab Sebagai Bahasa Kedua (Kajian Teoritis Pemerolehan Bahasa Arab Pada Siswa Non-Native)', Arabiyat, 2 (2015), 86-97

Thoyyibah, Anisatu, 'Idiom Bahasa Arab Dan Bahasa Indonesia Yang Berunsur Benda-Benda Alam (Kajian Sosiosemantik)' (UIN Sunan Kalijaga Yogyakarta, 2015)

—, 'Khutbah Thariq Bin Ziyad (Kajian Stilistika Arab)', Alfaz. (Arabic Literatures for Academic Zealots), 6 (2018), $109-26$ $<$ http://dx.doi.org/http://dx.doi.org/10.32678/alfaz>

Zulhannan, Teknik Pembelajaran Bahasa Arab Interaktif (Jakarta: Rajawali Pers, 2015) 